\title{
An Ancestral Caddo Ceramic Vessel from the Molly Cameron Site (41BW18) in the Sulphur River Basin in East Texas
}

Timothy K. Perttula

Heritage Research Center, Stephen F. Austin State University

Follow this and additional works at: https://scholarworks.sfasu.edu/ita

Part of the American Material Culture Commons, Archaeological Anthropology Commons, Environmental Studies Commons, Other American Studies Commons, Other Arts and Humanities Commons, Other History of Art, Architecture, and Archaeology Commons, and the United States History Commons

Tell us how this article helped you.

This Article is brought to you for free and open access by the Center for Regional Heritage Research at SFA ScholarWorks. It has been accepted for inclusion in Index of Texas Archaeology: Open Access Gray Literature from the Lone Star State by an authorized editor of SFA ScholarWorks. For more information, please contact cdsscholarworks@sfasu.edu. 
An Ancestral Caddo Ceramic Vessel from the Molly Cameron Site (41BW18) in the Sulphur River Basin in East Texas

\section{Creative Commons License}

\section{(c) (1) \&}

This work is licensed under a Creative Commons Attribution-NonCommercial 4.0 International License 


\section{An Ancestral Caddo Ceramic Vessel from the Molly Cameron Site (41BW18) in the Sulphur River Basin in East Texas}

Timothy K. Perttula

The Molly Cameron site is an ancestral Caddo habitation site with burial features in the Sulphur River basin in East Texas, specifically on Aiken Creek, a southward-flowing tributary, about one mile east of the dam at Lake Wright Patman (Figure 1). The site was first exposed in 1928, when plowing of the land owned by W. K. Cameron exposed several ceramic vessels and human remains. One of the vessels was purchased by The University of Texas at Austin in August 1932; that vessel is documented below.

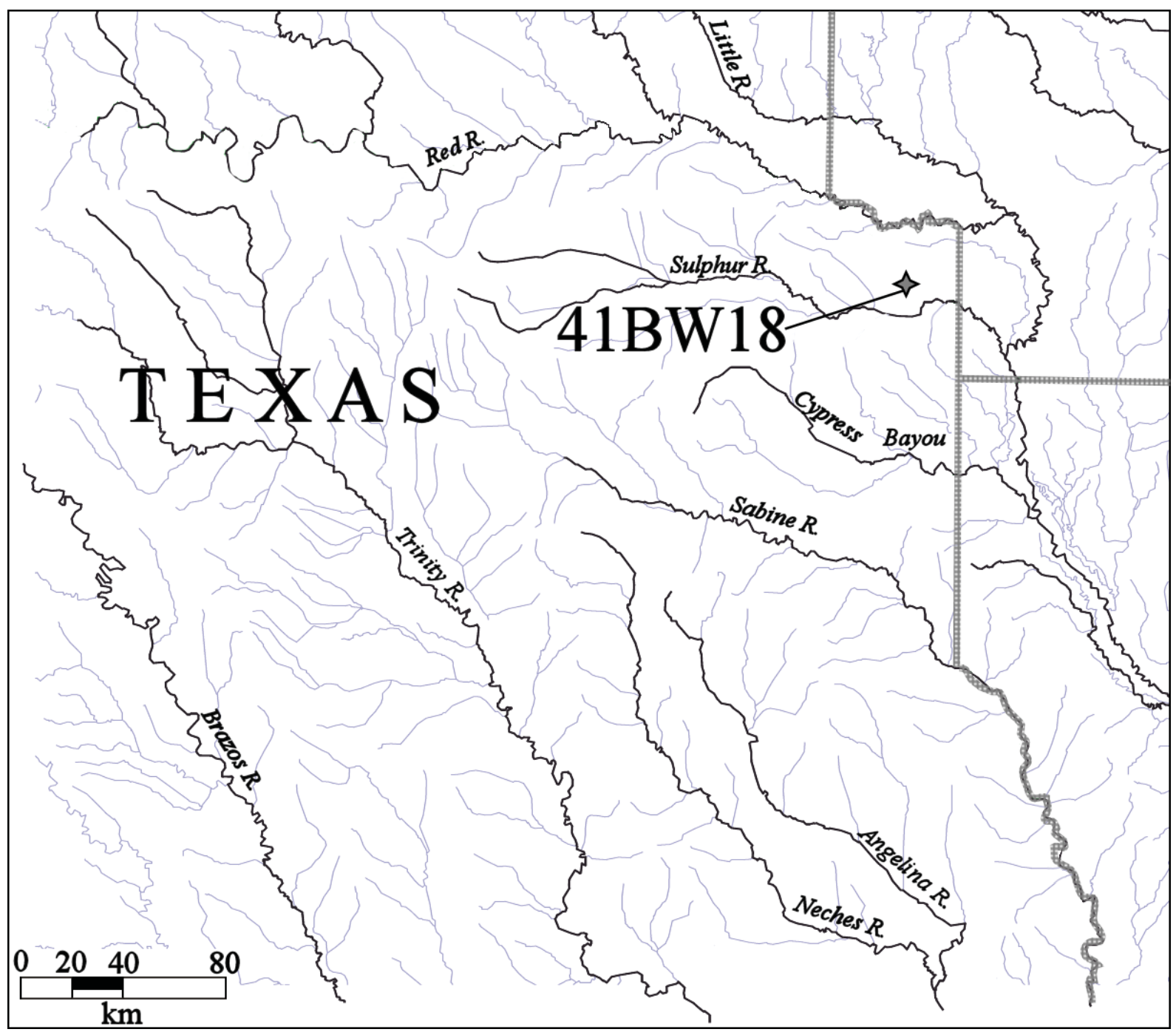

Figure 1. The location of the Molly Cameron site (41BW18) in Bowie County, Texas. 
During the survey of then proposed Lake Wright Patman in 1949, Robert L. Stephenson noted that the site, which he recorded as the Molly Cameron site, covered ca. 5-10 acres. He also noted that burials and vessels had been found by various individuals, but he was unable to obtain any specific information about these finds. Stephenson did collect 21 grog-tempered ceramic vessel sherds from the site, including 19 that were undecorated, one incised sherd, and one engraved sherd.

SITE NAME OR SITE NUMBER: Molly Cameron (41BW18)

VESSEL NO.: 1, W. K. Cameron Collection

VESSEL FORM: Jar

NON-PLASTICS AND PASTE: grog

RIM AND LIP FORM: Everted rim

CORE COLOR: B (fired and cooled in a reducing environment)

INTERIOR SURFACE COLOR: very dark gray

EXTERIOR SURFACE COLOR: very dark gray; organic residue on the vessel body

WALL THICKNESS (IN MM): rim, $4.2 \mathrm{~mm}$; body, $6.0 \mathrm{~mm}$

INTERIOR SURFACE TREATMENT: smoothed

EXTERIOR SURFACE TREATMENT: none

HEIGHT (IN CM): 9.7

ORIFICE DIAMETER (IN CM): 9.8

DIAMETER AT BOTTOM OF RIM OR NECK (IN CM): 8.9

BASE DIAMETER (IN CM) AND SHAPE OF BASE: $6.4 \mathrm{~cm}$, circular and flat

ESTIMATED VOLUME (IN LITERS): 0.6

DECORATION (INCLUDING MOTIF AND ELEMENTS WHEN APPARENT): The rim of the vessel is plain, but the vessel body has a continuous series of 42 narrow vertical appliqued ridges that extend to just above the vessel base (see Suhm and Jelks 1962:Plate 13e-f).

PIGMENT USE AND LOCATION ON VESSEL: none

TYPE AND VARIETY (IF KNOWN): Cass Appliqued

Cass Appliqued vessels are known from ancestral Caddo sites in the Sulphur and Big Cypress Creek basin in East Texas that were occupied from the $16^{\text {th }}$ century to the early $18^{\text {th }}$ century (Perttula et al. 2010), including sites in Cass County with European trade goods. This suggests that the Molly Cameron site, or at least one burial feature at the site, was occupied sometime during that time range. At the Goode Hunt (41CS23) and Clements (41CS25) sites, these vessels were associated with late $17^{\text {th }}$-early $18^{\text {th }}$ century Nasoni Caddo settlements. 


\section{References Cited}

Perttula, T. K., B. Nelson, R. L. Cast, and B. Gonzalez

2010 The Clements Site (41CS25): A Late 17 th to Early $18^{\text {th }}$-Century Nasoni Caddo Settlement and Cemetery. Anthropological Papers No. 92. American Museum of Natural History, New York.

Suhm, D. A. and E. B. Jelks (editors)

1962 Handbook of Texas Archeology: Type Descriptions. Special Publication No. 4, Texas Archeological Society, and Bulletin No. 4, Texas Memorial Museum, Austin. 